2017-05-02

\title{
Cooking with offenders to improve health and well-being
}

\author{
Parsons, Julie Milroy
}

http://hdl.handle.net/10026.1/10698

10.1108/BFJ-10-2016-0453

British Food Journal

Emerald

All content in PEARL is protected by copyright law. Author manuscripts are made available in accordance with publisher policies. Please cite only the published version using the details provided on the item record or document. In the absence of an open licence (e.g. Creative Commons), permissions for further reuse of content should be sought from the publisher or author. 
This is a final author's draft of an article accepted for publication the British Food Journal DOI: 10.1108/BFJ-10-2016-0453

Accepted: $17^{\text {th }}$ January 2017

Published: $02^{\text {nd }}$ May 2017

Title: Cooking with offenders to improve health and wellbeing.

\section{Abstract:}

Purpose: This paper demonstrates the benefits of cooking one-to-one, alongside commensality (eating together) for improving offender/ex-offender health and well-being, measured in terms of improved social skills, cultural competencies and successful resettlement.

Design/methodology/approach: Fieldwork conducted over nine months included; participant observation of lunch times $(n=56)$, cooking one-to-one with trainees $(n=27)$, semi-structured interviews $(n=23)$ and a 'photodialogue' focus group with trainees $(n=5)$ and staff $(n=2)$.

Findings: Commensality is beneficial for offender/ex-offender health and wellbeing. Further, preparing, cooking, serving and sharing food is a powerful means of improving self-esteem and developing a pro-social identity.

Research limitations/implications: The original focus of the research was commensality; it was during the study that the potential for cooking as an additional tool for health and wellbeing emerged. A future longitudinal intervention would be beneficial to examine whether the men continued to cook for others once released from prison and/or finished at the RS.

Practical implications: Everyday cooking to share with others is an invaluable tool for improving self-worth. It has the potential to build pro-social self-concepts and improve human, social and cultural capital.

Social implications: Cooking lunch for others is part of strengths based approach to resettlement that values community involvement.

Originality/value: Cooking and eating with offenders/ex-offenders is unusual. Further hands-on cooking/eating activities are beneficial in terms of aiding self-confidence and self-respect, which are vital for improving offender/exoffender health and well-being.

\section{Introduction}

This paper reports on the benefits of cooking for offender/ex-offender health and well-being at an independently run rural resettlement scheme (RS) that works with men released for work experience on temporary licence (ROTL) from the local prison every day and others in the community referred through the local probation team, collectively referred to as trainees. The RS is a Charitable Incorporated Organisation ( $\mathrm{ClO})$, currently the only one of its type in the country, now in its 4th year. It works with men from the resettlement wing of the local prison who are coming to the end of their prison sentences and offers through the gate support, alongside training in a range of occupations (for example construction, landscaping, market gardening and woodworking). Trainees also engage in what might be considered more craft based activities such as art, pottery and woodturning. 
The RS is unique in its ethos, as each trainee develops a bespoke approach to their individual resettlement needs through a range of occupations and work with skilled staff/volunteers. There are also 1000+ registered supporters of the RS who invest time and/or money and who may engage with the RS through the daily community lunch, sales of produce at the gate and/or the annual supporters' day. It is notable that at the RS the cross fertilisation of highly individualised processes with the development of 'softer' social skills, as witnessed during the daily community lunch, other community events and indeed all activities across the scheme are significant for the trainees in developing a pro-social identity, forming positive personal relationships and widening social networks. Moreover, over the last 12 months cooking lunch for everyone on site has developed into a regularly activity for trainees, which is significant in terms of 'softer emotions such as hope, aspiration and cultural belonging' (Farrall et al 2010:555), and the opportunity it allows trainees 'to show a different, softer and more approachable side' (Nugent and Loucks, 2011:363). Although the RS is unique, cooking and eating together are transferable activities that could offer benefits to other schemes working with vulnerable groups.

The findings that inform this paper come from a small-scale qualitative research project carried out during a 12-month Sociology of Health and IIIness Foundation (SHI) Mildred Blaxter post-doctoral fellowship. The research was conducted over nine months in the field (October 2015 - June 2016), examining commensality (eating together around a table, from the Latin cum mensa in the company of a meal/table, cited in Parsons 2015a) as a tool for health, wellbeing, social inclusion and community resilience. The premise is that the daily lunch shared with members of the community on site (2-3 days a week) is beneficial for both trainees and visitors alike. The focus on commensality was deliberate because although trainees engage in a variety of other activities over a working day at the RS that helps to develop human capital (capacities, training) (Sennett 2003), when moving from an offender to non-offender identity, social reaction is important, and this change in behaviour needs to be recognised by others and reflected back (McNeill and Weaver 2010).

Positive change is reflected back to trainees by staff and volunteers at the RS, but it is only during lunchtimes that visitors, supporters and stakeholders from the wider community are permitted onto the site. The working day at the RS was developed to mimic an ordinary working day, with a coffee break in the morning, followed by lunch at 13:00 and a tea break in the afternoon. This began four years ago with contributions for lunch supplied by a local environmental college, consisting of vegetarian soup, bread and cake/ biscuits. Then once a kitchen was built on site it was possible to cook meals and cooking lunch developed into another opportunity for one-to-one working with trainees, led by key volunteers and supporters, gradually increasing from cooking lunch one day per week (April 2015), to two days per week (January 2016) to three days per week (May 2016). Preparing and cooking lunch oneto-one with trainees on site is now an established activity and part of a trainees' bespoke resettlement plan. Indeed 'research has shown that handson cooking activities are a successful way to improve mealtime practices and 
eating habits of families' Condrasky et al (2006:324) (see also, Meloche 2003, Horodynski et al 2004). It is notable that those who cook with trainees are not professionals, trained chefs or dietitians, but interested in working with the trainees and/or passionate about cooking. There are two regular cooks (Tuesdays and Thursdays every week, including the researcher) and around ten other regular visitors who cook on a rota basis on Wednesdays. This raises questions as to what is meant by cooking, for the purposes of this paper it refers to the 'application of heat to fresh, raw ingredients prepared from scratch' (Meah and Watson, 2011:1:7, following Short 2006:07).

Further in terms of the health benefits of commensality and cooking, Her Majesty's Inspectorate of Prisons (HMIP) recently published a report on Life in Prisons: food, (2016). They argue that:

instilling healthy eating habits aids in rehabilitation and reintegration into the community after release... A major part of rehabilitation is education about and the promotion of a healthy lifestyle, and a crucial component of this is a healthy, balanced diet.

Indeed, the HMIP findings report highlights how interconnected food is with health and well-being, with a lack of control over 'what, when, where or how much they eat' (HMIP 20016: 3) a potential source of frustration and anxiety for prisoners. Indeed, as recognised by the World Health Organisation:

[a]n understanding of the role of food in correctional settings and effective management of food systems may improve outcomes for incarcerated people and help correctional administrators to maximise the health and safety of individuals in these institutions. (Smoyer and Minke 2015)

The HMIP makes four recommendations to the National Offender Management Service (NOMS), who operate most of the prison estate, firstly that the nutritional values and conditions under which food is eaten should be set as a standard with input from professional bodies. Also, that prisoners should have the opportunity to eat communally (most food is eaten in prison cells), to eat at times considered normal for the rest of the community (meals are often served at odd times, for example lunch at 11:10 or dinner at 16:15) and to have opportunities for self-catering, especially for long-term prisoners. It is notable that the cooking and eating activities at the RS can be loosely aligned with these recommendations, and are indicative of the potential benefits for offender/ex-offender health and well-being of hands-on cooking activities alongside commensality.

In terms of the resettlement literature, the RS makes use of a strengths based approach that considers reparation, reconciliation and community partnership significant, with a focus on the benefits or good deeds that the reformed offender can offer the community (Hucklesby and Wincup 2007). Further, commensality is important for developing social capital (social networks) (McNeill and Weaver 2010) as the social recognition and acceptance of the reformed ex-offender by the community is vital for successful resettlement 
(McNeill 2012:18). Moreover, cooking and commensality exposes trainees to forms of cultural capital (Bourdieu 1984), which are also beneficial for health and wellbeing, although neglected in the resettlement literature. Cultural capital following Bourdieu (1986) refers to lifestyles, tastes, cultural competencies and participation. It is therefore through an investment in human, social and cultural capital as performed through everyday cooking for others, that trainees begin to 'gain a stake in conformity' (McNeill and Weaver 2010:54), which is ultimately beneficial for health, well-being and significantly for successful resettlement.

\section{Background}

As a social group, 'prisoners remain the most vilified, marginalised and excluded in society' (McNeill and Weaver 2010:28). Moreover, the negative impact of marginalisation, exclusion and stigma on health and wellbeing is well documented, particularly amongst those that focus on explaining persistent inequalities in health (Blaxter 2010, Nettleton 2006 Scambler 2003). This 'lethal combination of stigma, social exclusion, social learning, temptation, addiction, lack of social bonds, and dangerously low levels of human and social capital' can make successful resettlement and desistance from crime difficult (Barlow and Maruna, 2012:136). In terms of measuring health and wellbeing, the World Health Organisation (WHO 2006) defines health as ' ... a state of complete physical, mental and social wellbeing and not merely the absence of disease or infirmity'. The inference is that to experience health, a person must simultaneously be in a state of wellbeing. This raises questions regarding the value of 'complete', which potentially renders most people as not healthy for most of their lives. Moreover, it negates that capacity of individuals living with chronic disease and disability to be able to live fulfilling lives and to experience a feeling of wellbeing (Huber et al 2011). However, the emphasis on 'social' wellbeing is pertinent when exploring the benefits of everyday cooking for others, as well as the role of social capital when examining theories of resettlement. Further offenders are constantly under scrutiny and on guard in prison (Crewe and Bennett 2012) due to the intense regulation of everyday life, typical of a 'total institution' (Goffman, 1961). Prisoners rarely have 'normal' conversations and can close down emotional responses in order to cope inside, as:

...doing time stifles self-awareness and the awareness of others, freedom of self expression is rigorously controlled and meaningful social interaction curtailed... prisoners are objects whose individuality is held to be subservient to the larger needs of the prison ... autonomy, reflection are significantly reduced...' (Flynn 2010:105)

On the other hand, engaging in work with and for others (e.g. cooking lunch), has the potential to demonstrate care of the self, others and the future, which are dispositions associated with successful resettlement, that signify a shift in cultural habitus. At the RS cooking and commensality are both types of 'pure sociability or association for its own sake' (Simmel and Hughes 1949:254) that helps trainees develop pro-social identities, social networks, benefits health and wellbeing and ultimately challenges negative stereotypes of offenders. Indeed, it is argued that sociability 'enhances human growth and social 
wellbeing by generating a sense of cooperation, commonality and belonging' (Anderson 2015: 103). Moreover, that taking responsibility and caring is identified as vital in developing a pro-social self and aiding desistance (Barry 2007, Healy 2010, Hucklesby and Wincup 2007). Further, the belief offenders' have in their own abilities to reform are significant because 'even prisoners need to be useful to others [in order] to discover their own hidden uses' (Barlow and Maruna, 2012: 138). The focus of this paper is on cooking and draws upon interview transcript data. The argument is that trainees benefit through cooking lunch for others, they develop valuable everyday life-skills, as well as human, social and cultural capital. Significantly it is part of a strengths based approach to resettlement (Hucklesby and Wincup 2007) that enables trainees to gain social recognition through cooking and commensality.

Indeed, in strengths based approaches to resettlement offenders take responsibility for the self and others, and need to be seen to be doing good deeds (Hucklesby and Wincup 2007). They are considered to have something to give to the community rather than 'lacking' in terms of skills and training. It is argued that 'real integration should involve earning one's place back in the moral community' (Burnett and Maruna 2006:84). Moreover, according to Mimi Silbert, one of the primary promoters of the Delancey Street Foundation in San Francisco:

Nobody should be only a receiver. If people, are going to feel good and be accomplished and be part of something, they have to do something they can be proud of... So if we want them to be pro-society, then we ought to set up vehicles that help them to be somebody in more traditionally positive ways (cited in Boschee and Jones, 2000:5)

Transforming rehabilitation is on the UK government's political agenda, as reoffending costs the economy an estimated $£ 13$ billion (Ministry of Justice 2013). Although, there is no coherent theory of resettlement (Hedderman 2007:10), social integration and acceptance by the wider community are vital to combat recidivism and aid desistance (McNeill 2006). Indeed, over the last decade, desistance theories have developed as a challenge to rehabilitation paradigms that focus on public risk and highly individualised psychological interventions (McNeill 2006, McNeill 2012, Owers 2011). The argument is that the 'problem' of desistance is social as well as individual; it is not just a 'private' business (McNeill 2012). Hence, some theorists focus on the need to improve human capital (capacities, training) (Sennett 2003) whilst others place greater emphasis on social capital (social networks) (McNeill, 2012). However, these positions tend to neglect the interdependence of these forms of capital with economic (investments, savings) and cultural (personal tastes) capital (Bourdieu 1984). Indeed for an individual habitus to change it needs to be exposed to a range of new experiences and environments in order to develop alternative dispositions, expectations and aspirations (Bourdieu 1984, Reay 2004).

\section{Methods}

The lunchtime meal at the RS is shared with everyone on site that day, with numbers from a minimum of 9 up to a maximum of 14 people (an average of 
about 12). A wide variety of people visit for lunch and this is encouraged to enhance social integration (Hedderman 2007). Lunch is an act of 'table fellowship' (Coveney 2006:33), developed specifically to encourage social inclusion, to build links between trainees and the wider community and for trainees to develop social skills and tastes in food they might not otherwise have experienced. It is widely accepted amongst food scholars that early food experiences are significant in shaping identity, (Parsons, 2014a, 2015a) whilst commensality fosters a sense of social inclusion and solidarity (Fischler 2011, Grignon 2001). Sharing these everyday foodways (ways of doing food) and cooking for others has the capacity to create and re-create social bonds and values (Sutton 2001). Arguably we eat nothing in isolation, but as part of a culture, so that we feed not only our appetites but also our social values and desire to belong (Fiddes 1991). This connection works both ways in terms of fostering inclusion and acceptability amongst trainees and the wider community.

The University Ethics Committee granted full ethical approval for the study in October 2015. The fieldwork for the study was then carried out over nine months, finishing in June 2016. All participants gave written consent to be part of the participant observation element of the fieldwork, as well as for the focus group and semi-structured interviews. All participants were given (or chose) pseudonyms (fake names). Most interviews were conducted on site after lunch (two were conducted in the interviewee's home and one in their place of work). All staff, trainees and volunteers working at the RS at the time of the study were interviewed. Stakeholders and supporters were selected for interview about visiting for lunch based on the length of time they had been involved. In terms of trainees the men released on temporary licence (ROTL) from the prison everyday come from the resettlement wing of the local prison. This houses 34 men out of a prison population of c.750. These men have earned this privilege through exceptionally good behaviour. ROTL is not a right, but if granted men choose a work placement at the RS up to 12 months before the end of their prison tariffs to prepare them for release into the community on licence, importantly helping them to secure employment and accommodation.

The researcher is a sociologist, published in the sociology of food, families and health and a volunteer at the RS. The original research programme was developed to explore commensality and therefore focussed on examining the experiences of those who had attended for lunch. The focus on the benefits of cooking only emerged as the research progressed. All interviews were audio recorded, transcribed verbatim and lasted from 30 minutes to 2 hours. In total $n=23$ interviews were conducted as follows, staff $n=4$, stakeholders $n=2$, supporters $n=6$, trainees $n=7$ and volunteers $n=4$. A photo-dialogue focus group on the topic of food likes and dislikes was conducted on site with seven men (staff $n=2$ and trainees $n=5$ ). The researcher kept field notes on every visit ( $n=7$ A5 notebooks), wrote a closed interactive blog detailing the research process/progress for her research mentor ( $n=14$ blog posts), participated in $n=56$ lunches and cooked $n=27$ one-to-one with the trainees. 
An iterative and reflexive approach was adopted (Denscombe 2010) for this case-study, in keeping with a constructivist grounded theory perspective (Charmaz 2006). Analysis began with the first interview and was discussed and verified with the research mentor for the duration of the study. A further thematic analysis was conducted on all interview $(n=23)$ and focus group ( $n$ $=1$ ) transcripts. This involves a search for themes that might be considered relevant to the description of the phenomenon (Daly, Kellehear, and Gliksman, 1997) through 'careful reading and re-reading of the data' (Rice and Ezzy, 1999: 258). These open themes (codes) (Strauss and Corbin 1990) capture key aspects of the thematic content and are a form of pattern recognition within the data, where themes become categories for analysis. Evidence is included here from the transcripts of interviews with two long-standing key volunteers, Carole and Donald, alongside data from staff (Charlie, Jenna and Neil) as well as Carly (stakeholder) and Marcia (supporter).

\section{Results/Discussion \\ Responsibility and recognition}

The results and discussion are interwoven and focus on the benefits of cooking one-to-one for the health and well-being of offenders, especially as a means of demonstrating responsibility and the need for this to be recognised, as well as the opportunities it affords for talking and doing normal as trainees work towards 'gaining a stake in conformity' (McNeill and Weaver, 2010:54). Three broad interconnected themes were identified within the data, verified by the research mentor and shared with participants. These focussed upon human (skills, training), social (networks, bonding) and cultural (tastes, lifestyle) capital, as both commensality and cooking enables trainees to practice in these fields and to have good deeds recognised by the wider community and reflected back.

Most trainees when they first arrive at the RS enter the kitchen with some trepidation and claim to have never cooked and certainly not for other people. A member of staff, Charlie, sums up the RS approach to cooking lunch for others and states:

...so it's about them starting to take some responsibility, not just for themselves but around others, so by cooking [for example] people move out of themselves a little bit and start to provide a meal for others so they are actually taking responsibility for other people and also that they can feel the enjoyment and satisfaction from that as well.

Carly (stakeholder), in her interview on commensality says:

I think the RS really helps them, obviously because you've got this cooperative where everyone takes it in turns to cook or wash up, take turns on veg and learn new trades and everyone's treated you know as an individual... because some people have never cooked for themselves and that's important if they're going to leave prison and live on their own a lot of them have only ever eaten you know Gregg's pasties and KFC and to make food themselves you know to make basic meals, and you know some of the meals are far from basic aren't 
they, to be able to learn to cook that and make things I think that's good, yes and that's something you wouldn't necessarily associate with the RS, it's valuable.

Hence, although Carly is identifying what offenders 'lack' in terms of human capital (skills and training), she does note that they are working together as a team, which is something Carole, also comments favourably on the benefits of cooking together for others, she says: "to work with somebody doing it [the cooking], and to get praise for it from the group, because they do have to operate as people on their own in prison". This is also reinforced in the interview on commensality with Neil, he remarks:

But this whole thing about cooking together I just think... having got the kitchen built and being able to cook here I just think it's a huge value on the whole project... I think doing [the cooking] here - this is more special isn't it, you can just sit and thank the people at the end of the meal... and to be honest it's part of the project - if you took somebody like Frank who I bet you can't fry an egg - no, if you could get him after six months here, being able to leave being able to maybe do a few very basic things, simple stuff - would be quite an achievement.

There are several issues highlighted here, there is an emphasis on what the trainees 'lack' in terms of cooking skills, the benefits of working together, but also it's about praise and acknowledgement. The men who cook the meal serve it to the others and are thanked for their efforts. Indeed, the project coordinator, Jenna in her commensality interview says:

...it's also about people being thankful for food, it's OK because you know, when they get food in the prison you're not - it's just - like, it's just delivered to them, they've got to eat it, blah-blah-blah, but here you know, you end up, you know, people thanking you for it ... when you add them up it's probably about 20 thank you's a day throughout it and it's just - that really, that's the difference because that changes, people feel really like, they do feel grateful for the food - for example when somebody says to Nolan what do you think of the bread? And it was alright... it is that, it's quite difficult for people, for anyone to take praise.

Again, this is about social recognition but also responsibility. Jenna clearly identifies how food is just 'delivered to you' in prison; the men are not responsible for it, whereas at the RS they are complimented for cooking. They are doing something positive for others, although this recognition is not necessarily easy for them to acknowledge, as John a trainee also notes in his interview:

l've noticed... people tend to get very embarrassed when they cook something nice... like with the sausage casserole with you and he [Ryan] was there dishing it out and that, and I was 'oh this is nice what's in that?' and he was 'well it was... so he enjoys doing it when he's doing it, but then he makes out he doesn't... 
Here, John is highlighting how difficult it is for trainees to be complimented for their efforts. It is notable that Ryan wants to explain to John how the dish is made, despite feigning a lack of interest in cooking generally. Indeed, 'pride' is a common thread throughout the transcripts, particularly when commenting on cooking at the RS. Although, 'pride' can have negative connotations, in this context it is significant for trainees in terms of increasing self-esteem, selfrespect and self-confidence. In her interview on commensality, Marcia, a longstanding supporter of the RS and frequent lunchtime visitor observes:

...because they're cooking the effort's in there and the pride. What I did notice one time that I was here [at the RS] and Carole was here, was there was a lot of pride involved and that I thought, that alone was... oh it was a couscous thing that's right... And it was delicious it was really nice quite simple, but I was thinking you know, making something and giving for other people to share is what you and I do everyday, but it is a pride thing... You feel pleased that people are enjoying it so that's a real positive I would have thought.

Again, Marcia is emphasising the benefits of social recognition for 'doing' something for others that enhances social wellbeing through a sense of cooperation, commonality and belonging. The trainees are engaging in an everyday cultural 'norm' that means trainees are potentially working towards 'gaining a stake in conformity' (McNeill and Weaver 2010:54). In Carole's interview on commensality she recalls working with Bradley, she notes:

I said to Bradley we're going to do an Eton Mess [for pudding] and he had no idea what an Eton Mess was - I told him what to do and he made this Eton Mess and I have an enormous bowl about this big and we made this enormous pile of Eton Mess... and he was so thrilled - he was so thrilled and he went and got - I can't remember who it was who had a phone and he wanted his photograph taken - with this Eton Mess and I just thought that was, I was so touched by that, so touched.

In this excerpt Carole is recalling a time when she had a lot of left over meringue from an event she had been hosting and decided to bring them into the RS to share with everyone after lunch. This raises a couple of interesting issues, firstly that Bradley did not know what this was and secondly he took pleasure in making and sharing it. Indeed, Bradley unprompted in his interview also mentions the Eton Mess, he says:

I've got a photo of that [Eton Mess] on my Facebook... you know with strawberries... look what l've done today... I enjoyed it...

The benefits of cooking and sharing food are therefore beneficial for selfesteem, human, social and cultural capital. Indeed, when interviewing Donald about commensality, he remarks:

John produced this nice loaf of bread which you know, he's done that two or three times now, but he's really proud of his loaves of bread and everybody ate it and genuinely enjoyed eating it, so they weren't just 
kind of buttering him up - so I think for him that's a real good thing to have you know, being appreciated for what you've made.

Again, cooking something to share elicits a sense of achievement and pleasure; both food and baker are appreciated and praised.

\section{Talking and 'doing' normal}

Another aspect of cooking one-to-one is the opportunity it affords to talk and share confidences, as noted earlier there is an element of being locked down emotionally when coping with everyday life inside (Liebling 1999, 2001, Jewkes 2012a, 2012b, Crewe and Bennett 2012), as Ryan says in his interview:

...before I came out here I thought it was about going to work, doing your days work and then going back, I didn't realise that there was so much more effort in getting you to socialise and you know open yourself up a bit, which is you know exactly what I needed... I didn't expect it to be so helpful if you know what I mean? I thought it was just a matter of coming out here and doing a days work and going back. I was fine with that, but I didn't realise how much, how strange l'd become, basically with the barriers I'd built up while I was in prison, so yeah l'd say that was the unexpected bit, how strange l'd become and how much I needed you know to do things differently...

Indeed, as Carole comments cooking one-to-one enables trainees to engage in 'normal', everyday conversation and in addition, she adds:

It's this whole business about when you cook you're not looking at somebody - it's a huge thing and... they all talk non-stop but John particularly, he said things that - he said I haven't told anybody this and it was - it was about what it was about going into prison for the very first time and he was so upset, he used to wet the bed - so you've got this $40+$ guy wetting the bed and he said I've never told anybody that and I'm telling you, but you know, but - and I just thought if we weren't cooking he wouldn't have told me that - they - they are very honest when they're cooking... because you haven't got that eye contact, and it's very easy to ask a question and because they don't feel threatened - because they're busy, that they'll often be very truthful in their answer, I think... it's hugely beneficial in that respect...

Hence, there is also a confessional element to cooking one-to-one that is beneficial for trainees when coming to terms with their experiences. Further when reflecting on her work with John, Carole continues:

Actually John said l'd never thought when somebody said to me oh you'll be doing things like cooking, he said I thought oof - you know, what's that? And [now] he said I just love it, and he said how important he felt it was, and how it was like being part of a family - he talks - he 
actually talks non-stop when he cooks, non-stop, but that's fine because it's just he and I, and you know, he can - you know, he presses his button - his talk button and he goes and that's good for him because you can't do that in prison [have] just a normal conversation

Similarly, Donald in his commensality interview says:

I think making is a really important thing because it's physically engaging... and it enables you to have conversations with people you're with and it enables you to kind of define who you are a bit - and you get a sense of satisfaction, you've got something at the end of it that you can take away or use or eat

Again, working closely with someone is about sociability and re-learning how to interact and be 'yourself' in a non-judgemental environment. Indeed, as Paul a trainee said in his interview:

I like the one on one personal time that you have with people that what's I enjoy about cooking and that's what I enjoy about doing stuff I like to do... because it's good to talk to someone one on one and if you're cooking, yes you've got that you're in [it] together...

Hence, cooking together is an opportunity to talk; it also provides trainees with an opportunity to give something to others. The making and sharing of food helps to build self-esteem and confidence, as Ryan noted in his interview:

...I did like the chatting to Carole [when cooking] and chatting to people - I suppose the one good thing about it is it - it breaks it up if you're doing something it's easier to chat to somebody when you've got something to do.

Indeed, Ryan was negative about cooking believing it to be a highly mundane and feminised activity, despite being a good and initiative cook. However, all trainees are involved in cooking lunch on a rota type basis, and even Ryan could see the benefits of it for developing social capital and sociability in preparation for release.

\section{Concluding Comments}

Overall cooking together, then serving and sharing this lunchtime meal with others, is highly beneficial for the health and wellbeing of trainees at the RS. It affords them an opportunity to give something back to others working at the $\mathrm{RS}$, but also to the wider community who may also be visiting for lunch. It is a form of reparation that can help in terms of reintegration and de-stigmatisation (Hucklesby and Wincup 2007:56). To develop a pro-social identity, offenders need to feel they are part of something and that they belong. Evidence therefore suggests that cooking for others not only improves human capital (skills and training), but also social (networks) and cultural (tastes) capital. It is valuable in fostering self-confidence and self-esteem, as trainees feel proud of 
what they have produced for others. Indeed, it is the sociability of cooking the lunchtime meal from the one-on-one time working with a volunteer, to the praise received as they serve the food, to the commensal occasion of sitting and eating together in the company of a meal/table, which is beneficial. Hence, everyday cooking to share with others is an invaluable tool for improving selfworth. It has the potential to build pro-social self-concepts and improve social and cultural capital. Indeed, findings reveal that commensality and cooking are useful tools for enabling trainees to demonstrate both individual and social responsibility. Cooking one-to-one is also particularly beneficial in terms of the health and wellbeing of trainees, through improvements in self-esteem, selfconfidence and sociability. Moreover, although the RS is a unique case-study, these findings are transferrable in terms of the benefits of cooking for other marginalised and excluded groups, as a route to improved self-esteem and therfore health and well-being.

In terms of generalisability, this is only a small-scale, exploratory case-study and it is therefore not possible to generalise. However, in future, it would be useful to conduct a longitudinal evaluation of cooking as a specific intervention at the RS (see Akbar et al 2013). Also, the original research focus was on commensality and not cooking, instead the interest in cooking one-toone with trainees was something that developed at the RS as the research progressed. On the other hand, cooking was a significant theme to emerge from analysis of the transcript data. It is also arguably difficult to analyse cooking and/or commensality as distinct and separate from the overall benefit for the trainees of being involved with the RS. However, lunch is the only time when trainees can interact with the public and it is this which has the potential for de-stigmatising and challenging stereotypes of offenders. Thus cooking and/or commensality can be seen as part of a strengths based approach to resettlement that enables trainees to earn their 'place in the moral community' (Burnett and Maruna 2006:84).

\section{Acknowledgements}

This research was carried out during a 12 month Sociology of Health and IIIness Mildred Blaxter post-doctoral research fellowship (2015-16). I would like to thank the two anonymous reviewers. Also, my research mentor Professor Gayle Letherby for comments on an early draft of this paper.

\section{References}

Akbar, T., Everington, T., Richards, D., Themessl-Huber, M., and Freeman, R. (2013). The evaluation of the basic cooking skills/healthy eating (BaCE) programme for young offenders at Polmont. Dundee: University of Dundee, Dental Health Services Research Unit. Downloaded 30/11/2016 http://discovery.dundee.ac.uk/portal/files/3398888/BaCE Polmont evaluation. $\underline{\mathrm{pdf}}$

Anderson, S. (2015) Sociability, the Art of form, in Amit, V. (2015) Thinking through Sociality, An Anthropological interrogation of Key Concepts, Oxford: Berghan Books, pp 97-128. 
Barry, M. (2007) Youth Offending and Youth Transitions: The Power of Capital in Influencing Change, Critical Criminology, 15 (2): 185-98

Barlow and Maruna (2012) Rehabilitation, generativiity and mutual aid, in Crewe, B. and Bennett. J., (eds) The Prisoner, Routledge, London, pp131-141

Blaxter, M. (2010) Health. Cambridge: Polity.

Boschee, J. and S. Jones (2000) Recycling Ex-Cons, Addicts and Prostitutes: The Mimi Silbert Story. Institute for Social Entrepreneurs, Occasional Series, No.1. http://www.socialent.pdfs/MimiSilbertStory.pdf

Bourdieu, P. (1984) Distinction, A Social critique of the Judgement of Taste, London: Routledge.

Bourdieu, P. (1986) The forms of capital, in Richardson, J. (ed.) Handbook of Theory and Research for the Sociology of Education, New York: Greenwood.

Burnett, R. and Maruna, S. (2006) The kindness of prisoners: Strengthsbased resettlement in theory and in action, Criminology and Criminal Justice, Vol: 6 (1): 83-106

Charmaz, K. (2006) Constructing Grounded Theory, London: Sage.

Condrasky M, Graham K, Kamp J. (2006) Cooking with a Chef: An innovative program to improve mealtime practices and eating behaviors of caregivers of preschool children. J Nutr Educ Behav, 38:324-5

Coveney, J. (2006) Food, Morals and Meaning, 2nd Ed., London: Routledge.

Daly, J., Kellehear, A. and Gliksman, M. (1997). The public health researcher: A methodological approach. Melbourne, Australia: Oxford University Press.

Denscombe, M. (2010) (4 ${ }^{\text {th }}$ edition) The Good Research Guide: For SmallScale Social Research Projects: for small-scale social research, Maidenhead: Open University Press.

Farrall, S., Bottoms, A. and Shapland, J. (2010) Social structures and desistance from crime, European Journal of Criminology, 7 (6), 546-570

Fiddes, N. (1991) Meat A Natural Symbol, London: Routledge.

Fischler, C. (2011) Commensality, Society and Culture, Social Science Information, 50: 3-4, 528-548.

Flynn, N. (2010) Criminal Behaviour in Context, Space, Place and Desistance from Crime, Abingdon: Willan Publishing 
Goffman, E (1961b) On the characteristics of total institutions: The inmate world, in D Cressey (ed) The Prison, Studies in Institutional Organisation and Change, New Your: Holt, Reinhart and Wilson.

Grignon, C. (2001) Commensality and Social Morphology: An Essay In Typology, from Scholliers, P. (ed), Food, Drink \& Identity, Cooking, Eating \& Drinking in Europe since the Middle Ages, Oxford: Berg, pp 23-36.

Healy, D. (2010) The Dynamics of Desistance, charting pathways through crime, London: Routldge.

Hedderman, C. (2007) Rediscovering resettlement: narrowing the gap between policy rhetoric and practice reality, Hucklesby, A. and HagleyDickenson L., (eds) Prisoner Resettlement, Policy and Practice, Abingdon: Willan Publishing, pp 9-25.

Horodynski MA, Hoerr S, Coleman, G. (2004) Nutrition Education Aimed at Toddlers: A pilot program for rural, low-income families. Fam Community Health, 27:103-113.

Huber M, Knottnerus A.J, Green L, van der Horst H, Jadad A. R, and Kromhout D, (2011) How should we define health? BMJ 2011; 343 :d4163 Hucklesby, A and Wincup, E. (2007) Models of resettlement work with prisoners, in Hucklesby, A. and Hagley-Dickenson L., (eds) Prisoner Resettlement, Policy and Practice, Abingdon: Willan Publishing, pp43-66.

Jewkes, Y. (2012a). Autoethnography and emotion as intellectual resources: Doing prison research differently. Qualitative Inquiry, 18, 63-75.

Jewkes, Y. (2012b). Penal Hell-Holes and Dante's Inferno. Prison Service Journal, 199, 40-44.

Liebling, A. (1999). Doing research in prisons: Breaking the silence? Theoretical Criminology, 3, 147-173.

Liebling, A. (2001). Whose side are we on? Theory, practice and allegiances in prisons research. British Journal of Criminology, 41, 472-484.

McNeill, F. (2006) A desistance paradigm for offender management. Criminology and criminal Justice 6: 39-62

McNeill, F. (2012) 'Four forms of 'offender' resettlement: Towards an interdisciplinary perspective' in Legal and Criminological Psychology 17 (1), 18-36.

McNeill, F. and Weaver, B. (2010) Changing lives? Desistance Research and Offender Management, Available:

www.cepprobation.org/uploaded files/SCCJRReport 201003 Changing Liv es.pdf 
Meah, A., and Watson, W. (2011). Saints and slackers: Challenging discourses about the decline of domestic cooking. Sociological Research Online, 16, unpaginated, http://www.socresonline. org.uk/16/2/6.html Meloche J. (2003) Cooking with Class: Participation soars with hands-on learning and takeaways. J Nutr Educ Behav, 35:107-208.

Ministry of Justice, (2013) Transforming Resettlement: A Strategy for Reform, online:

https://consult.justice.gov.uk/digital-communications/transformingresettlement/results/transforming-resettlement-response.pdf

Nettleton, S. (2006) Sociology of Health and Illness (2nd edition). Cambridge: Polity Press.

Nugent, L and Loucks, N (2011) The Arts and Prisoners: Experiences of Creative Rehabilitation, The Howard Journal of Criminal Justice, Vol 50 No 4, pp. 356-370

Owers, A., et al. (2011) Review of the Northern Ireland Prison Service. Online: http://www.dojni.gov.uk/index/ni-prison-service/nips-publications/reportsreviews-nips/owers-review-of-the-northern-ireland-prison-service.pdf

Parsons, J. (2014a) 'Ourfoodstories@email.com', An Auto/Biographical Study of relationships with Food, PhD thesis, http://hdl.handle.net/10026.1/2920

Parsons, J. (2014b) 'Cheese and Chips out of Styrofoam Containers': an Exploration of Taste and Cultural Symbols of Appropriate Family Foodways, Media/Culture Journal, vol.17, No. 1, (online) http://journal.mediaculture.org.au/index.php/mcjournal/article/view/766

Parsons, J. M. (2015a) Gender, Class and Food: families, bodies and health, Palgrave MacMillan: Basingstoke.

Parsons, J. (2015b) 'Good' Food as Family Medicine: Problems of Dualist and Absolutist Approaches to 'Healthy' Family Foodways, Food Studies, An Interdisciplinary Journal, Volume 4, Issue 2, pp1-13.

https://cgscholar.com/bookstore/works/good-food-as-familymedicine?category_id=common-ground-publishing

Parsons, J.M. (2015c) The joy of food play - an exploration of the continued intersectionalities of gender and class in men's auto/biographical accounts of everyday foodways. Special Issue on 'Food' in Women, Gender and Research, Vol 24, no 3-4, pp 35-47.

Parsons, J. (2016) When convenience is inconvenient, 'healthy' family foodways and the persistent intersectionalities of gender and class, Journal of Gender Studies, Vol 25, No. 4, August, pp382-387. http://www.tandfonline.com/doi/abs/10.1080/09589236.2014.987656?journalC ode $=$ cjgs 20 
Reay, D. (2004) It's all becoming a Habitus: Beyond the Habitual Use of Habitus in Educational Research, British Journal of Education, 25 (4), 431444

Rice, P., and Ezzy, D. (1999). Qualitative research methods: A health focus. Melbourne, Australia: Oxford UniversityPress.

Scambler, G. (ed) (2003) Sociology as Applied to Medicine (5th edition). Edinburgh: Saunders.

Sennett, R. (2003) Respect in a World of Inequality. New York:Norton.

Short, F. (2006), Kitchen secrets: the meaning of cooking in everyday life. Oxford: Berg.

Simmel, G and Hughes, E (1949) The Sociology of Sociability, American Journal of Sociology, Vol 55 (3), pp254-261

Smoyer, A.B. and Minke L.K. (2015) Food systems in correctional settings: A literature review and case study. Copenhagen, DK: World Health Organisation Regional Office for Europe.

Strauss, A. and Corbin, J. (1990) (2 ${ }^{\text {nd }}$ edition) Basics of Qualitative Research: Grounded Theory Procedures and Techniques, London: Sage.

Sutton, D. (2001) Remembrance of Repasts, An Anthropology of Food and Memory, Oxford, Berg.

WHO (2006) Constitution of the World Health Organization www.who.int/governance/eb/who constitution en.pdf. 